\title{
Total bakteri asam laktat dan Coliform pada ileum dan sekum ayam broiler yang diberi Spirulina platensis dengan lama pemberian berbeda
}

\section{The amount of lactic acid bacteria and Coliform on ileum and caecum Broiler chicks that fed Spirulina platensis with different distribution duration}

\author{
Muhammad Irfan Sulfani*, Sugiharto, dan Turrini Yudiarti \\ Fakultas Peternakan dan Pertanian Universitas Diponegoro Semarang \\ Submitted : 28 September 2017, Accepted : 04 January 2018
}

\begin{abstract}
ABSTRAK : Tujuan penelitian ini adalah untuk mengetahui jumlah bakteri asam laktat dan Coliform dalam ileum dan sekum ayam broiler yang diberi Spirulina platensis dengan lama pemberian yang berbeda. Materi yang digunakan adalah 240 ekor day old chick (DOC) broiler dengan bobot awal rata-rata 42,015 $\pm 0,219$ g. Ayam broiler mendapat perlakuan antibiotik 0,04\% dan Spirulina platensis 1\% sebagai prebiotik dengan lama pemberian yang berbeda. Rancangan penelitian yang digunakan adalah Rancangan Acak Lengkap (RAL) dengan 4 perlakuan dan 5 ulangan. Perlakuan yang diterapkan yaitu T0 (Pakan Basal + 0,04\% Zinc Bacitracin), T1 (Pakan Basal $+1 \%$ Spirulina platensis selama 7 hari pemberian), T2 (Pakan Basal $+1 \%$ Spirulina platensis selama 21 hari pemberian) dan T3 (Pakan Basal + 1\% Spirulina platensis selama 35 hari pemberian). Pengukuran parameter dilakukan pada hari ke 32, pengambilan sampel dilakukan secara acak yaitu 1 ekor ayam dari masing-masing petak percobaan. Parameter yang diamati adalah total bakteri asam laktat dan Coliform. Data tersebut dianalisis keragamannya pada ketelitian 5\%. Hasil penelitian menunjukkan bahwa adanya pengaruh nyata $(\mathrm{P}<0,05)$ perlakuan yang diberikan terhadap total bakteri Coliform dalam ileum, namun tidak berpengaruh nyata pada total bakteri Coliform pada sekum dan total bakteri asam laktat dalam ileum maupun sekum. Kesimpulan dari penelitian ini menunjukan bahwa pemberian Spirulina platensis selama 3 minggu mampu menurunkan total bakteri Coliform dalam ileum.
\end{abstract}

Kata kunci: bakteri asam laktat, Coliform, ayam broiler, Spirulina platensis

ABSTRACT: This research was conducted to determine the amount of lactic acid bacteria and coliform inside the caecum and ileum of broilers. 240 days old chicks broiler (DOC) with $42.015 \pm 0.219 \mathrm{~g}$ average body weight were used in this research as an experimental objects. The chicks broiler were treated with $0.04 \%$ antibiotics and $1 \%$ Spirulina plantensis as a prebiotic under different interval ingestion. This experiment was constructed under completely random design (CRD) with 4 treatments and 5 repetition. The treatment that was applied were T0 (Poultry feed $+0.04 \%$ Zinc bacitracin), T1 (Poultry feed $+1 \%$ throughout 7 days), T2 (Poultry feed $+1 \%$ throughout 21 days), and T4 (Poultry feed $+1 \%$ throughout 35 days). The parameter measurements conducted in the 32 nd day with random sampling from each experiments. Total amount of lactic acid and coliform from each samples were observed and the variance was with 5\% accuration. The result showed the total amout of Coliform in ileum was significantly different $(\mathrm{P}<0.05)$ in the other hand the total amount of Coliform and acid bacteria in caecum were not influenced $(\mathrm{P}<0.05)$. It can be inferred that the Spirulina platensis treatment for 3 weeks reduced the total amount of bacteria inside caecum and ileum.

Keywords: lactic acid bacteria, Coliform, chicks broiler, Spirulina platensis

\footnotetext{
${ }^{*}$ Corresponding author: irfansulfani@yahoo.com
}

DOI: 10.21776/ub.jiip.2018.028.01.07 


\section{PENDAHULUAN}

Industri peternakan ayam broiler di Indonesia masih belum efisien dalam hal biaya produksi dibandingkan dengan Negaranegara di ASEAN. Biaya yang dikeluarkan untuk memproduksi $1 \mathrm{~kg}$ daging ayam broiler di Indonesia sebesar 0,80 US\$ lebih tinggi dibandingkan dengan Malaysia 0,63 US\$ dan Thailand 0,50 US\$ (Tangendjaja, 2014). Tingginya biaya produksi disebabkan oleh faktor pakan yang membutuhkan biaya yang cukup tinggi yaitu berkisar 70-80\% dari total biaya produksi. Berdasarkan hal tersebut peningkatan efisiensi pakan merupakan hal yang sangat penting. Masalah kesehatan juga merupakan hal lain yang sangat penting untuk diperhatikan. Beberapa literatur menyebutkan bahwa keseimbangan mikroflora di dalam saluran pencernaan sangat berpengaruh terhadap kesehatan ayam broiler.

Penggunaan feed additive merupakan salah satu solusi untuk menjaga keseimbangan mikroflora di dalam saluran pencernaan ayam broiler. Feed additive yang umum digunakan yaitu antibiotik, namun penggunaannya dibatasi bahkan dilarang di berbagai negara karena penggunaan antibiotik menyebabkan resistensi bakteri patogen, residu antibiotik juga dapat menimbulkan alergi dan kemungkinan keracunan (Murdiati, 1997). Alternatif pengganti AGPs untuk ayam broiler yaitu probiotik, prebiotik, asam organik, asam lemak, enzim, mineral organik, dan penikar racun (toxin binder) (Haryati, 2011). Prebiotik merupakan salah satu bahan yang dapat merangsang pertumbuhan dan aktivitas bakteri yang menguntungkan di dalam saluran pencernaan. Prebiotik yang di fermentasi di dalam kolon menghasilkan asam lemak rantai pendek (SCFA) dan asam laktat yang merupakan faktor penting yang menentukan $\mathrm{pH}$ lumen kolon (Senditya dkk., 2014). Nilai $\mathrm{pH}$ pada saluran pencernaan berpengaruh terhadap kehidupan mikroba. Nilai pH yang rendah dapat membunuh bakteri patogen, sehingga dapat menjaga keseimbangan mikroflora. Pada ternak yang sehat, komposisi mikroflora saluran pencernaan relatif tetap namun bila terjadi ketidakseimbangan mikroflora dapat menyebabkan kolonisasi mikroorganisme patogen yang dapat menimbulkan penyakit. Keberadaan bakteri menguntungkan di sekum perlu dipertahankan karena berpengaruh terhadap populasi bakteri menguntungkan yang dapat berimplikasi terhadap kesehatan saluran pencernaan ayam dan meningkatknya penyerapan nutrien (Krismiyanto, 2015).

Spirulina platensis tergolong kedalam cyanobacteria yang memproduksi zat yang dapat meningkatkan atau menghambat pertumbuhan mikroba (de Caire et al., 1987). Spirulina mengandung protein yang tinggi dengan asam amino yang cukup lengkap dan kaya akan polisakarida yang berfungsi sebagai sumber nutrien bagi bakteri asam laktat. Penggunaan spirulina sebagai prebiotik menunjukan hasil yang positif terhadap produktifitas dan kesehatan ternak. Menurut Jamil et al., (2015) penambahan Spirulina kurang dari $1 \%$ pada ayam broiler membuat sistem pertahanan tubuh menjadi meningkat dengan cara mengurangi atau membunuh mikroba patogen, dan meningkatkan aktivitas T-cell. Selain dapat meningkatkan produktifitas dan kesehatan, penggunaan spirulina pada level $0,2 \mathrm{~g} / \mathrm{kg}$ mampu meningkatkan efisiensi ekonomi menjadi 39,5\% (Mariey et al., 2014). Penggunaan feed additive terutama prebiotic umumnya diberikan selama masa 
pemeliharaan ayam broiler, namun untuk kepentingan efisiensi biaya produksi, lama waktu penggunaan prebiotik perlu ditinjau kembali. Kurangnya pustaka mengenai hal tersebut menjadikan minimnya informasi mengenai penggunaan prebiotik yang efisien. Hal tersebut menjadi salah satu landasan dilakukannya penelitian ini.

Tujuan dari penelitian ini yaitu untuk mengkaji lama waktu pemberian spirulina terhadap total bakteri Coliform dan bakteri asam laktat pada ileum dan sekum ayam broiler. Manfaat dilakukannya penelitian ini yaitu sebagai informasi penggunaan prebiotik secara efektif dan efesien.

\section{MATERI DAN METODE}

Materi yang digunakan dalam penelitian ini adalah 240 ekor day old chick (DOC) broiler dengan bobot awal rata-rata
42,015 \pm 0,219 g. Kandang yang digunakan adalah kandang koloni yang berukuran $1 \times 1$ $\mathrm{m}$ dengan jumlah 20 petak. Masing-masing petak berisi 12 ekor broiler. Perlengkapan dan peralatan kandang yang digunakan meliputi termohigrometer, tempat pakan, tempat minum, lampu penghangat dan blower. Peralatan analisis total bakteri asam laktat dan total Coliform adalah plastik klip, autoklaf, inkubator, oven, tabung reaksi, pipet, cawan petri, colony counter dan erlenmeyer. Bahan yang digunakan adalah, antibiotik zinc bacitracin, Spirulina platensis, MacConkey agar, MRS agar, dan anaerocult. Antibiotik yang digunakan dalam penelitian ini yaitu zinc bacitracin dengan dosis pemakaian 0,04\%.. Bahan pakan, persentase penggunaan serta kandungan nutrisi ransum disajikan pada tabel 1. Kandungan nutrisi Spirulina platensis disajikan pada table 2 . 
Tabel 1. Bahan pakan serta persentase penggunaan

\begin{tabular}{|c|c|c|c|c|}
\hline \multirow{2}{*}{ Bahan Pakan } & \multicolumn{4}{|c|}{ Persentase Kandungan Nutrisi Ransum } \\
\hline & T0 & T1 & $\mathbf{T 2}$ & T3 \\
\hline & \multicolumn{4}{|c|}{ 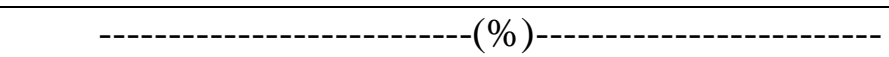 } \\
\hline $\mathrm{CPO}$ & 3,50 & 3,50 & 3,50 & 3,50 \\
\hline Dedak & 4,45 & 4,45 & 4,45 & 4,45 \\
\hline Jagung & 45,5 & 45,5 & 45,5 & 45,5 \\
\hline Tepung Gandum & 10,0 & 10,0 & 10,0 & 10,0 \\
\hline Tepung Roti & 5,00 & 5,00 & 5,00 & 5,00 \\
\hline MBM & 2,80 & 2,80 & 2,80 & 2,80 \\
\hline CFM & 2,00 & 2,00 & 2,00 & 2,00 \\
\hline CGM & 3,60 & 3,60 & 3,60 & 3,60 \\
\hline DDGS & 3,00 & 3,00 & 3,00 & 3,00 \\
\hline SBM & 17,0 & 17,0 & 17,0 & 17,0 \\
\hline Elthreonin & 0,08 & 0,08 & 0,08 & 0,08 \\
\hline Lisin & 0,55 & 0,55 & 0,55 & 0,55 \\
\hline Metionin & 0,37 & 0,37 & 0,37 & 0,37 \\
\hline Tepung Tulang & 1,50 & 1,50 & 1,50 & 1,50 \\
\hline Garam & 0,15 & 0,15 & 0,15 & 0,15 \\
\hline Premix & 0,50 & 0,50 & 0,50 & 0,50 \\
\hline Total & 100 & 100 & 100 & 100 \\
\hline Zinc Bacitracin & 0,04 & - & - & - \\
\hline Spirulina platensis & - & 1,00 & 1,00 & 1,00 \\
\hline Energi Metabolis (kkal/kg)* & 3.510 & 3.510 & 3.510 & 3.510 \\
\hline Protein Kasar $(\%)^{* *}$ & 21,9 & 21,9 & 21,9 & 21,9 \\
\hline Serat Kasar $(\%)^{* *}$ & 5,62 & 5,62 & 5,62 & 5,62 \\
\hline Bahan Kering $(\%) * *$ & 89,6 & 89,6 & 89,6 & 89,6 \\
\hline Lemak Kasar $(\%)^{* *}$ & 6,40 & 6,40 & 6,40 & 6,40 \\
\hline $\operatorname{Abu}(\%) * *$ & 6,39 & 6,39 & 6,39 & 6,39 \\
\hline
\end{tabular}

Keterangan : (*) Energi Metabolis (EM) dihitung berdasarkan rumus Balton (1967)

(**) Hasil analisis di Laboratorium Ilmu Nutrisi dan Pakan, Universtitas Diponegoro

Tabel 2. Kandungan Nutrisi Spirulina platensis

\begin{tabular}{|c|c|}
\hline Nutrisi & Kandungan Nutrisi \\
\hline & - \\
\hline Bahan Kering & 91,8 \\
\hline Protein Kasar & 52,4 \\
\hline Lemak Kasar & 0,63 \\
\hline Serat Kasar & 34,2 \\
\hline Abu & 11,3 \\
\hline BETN & 12,8 \\
\hline
\end{tabular}

Keterangan : Hasil Analisis di Laboratorium Ilmu Nutrisi dan Pakan, Universitas Diponegoro 
Rancangan penelitian ini tersusun dari 4 perlakuan dengan 5 ulangan, adapun perlakuan yang diterapkan yaitu T0 (kontrol), T1 (penggunaan Spirulina selama 1 minggu), T2 (penggunaan Spirulina selama 3 minggu) dan T3 (penggunaan Spirulina selama 5 minggu). Pengambilan sampel isi usus halus dan sekum dilakukan pada pemeliharaan hari ke 35. Pengambilan dilakukan secara acak yaitu 1 ekor ayam dari masing-masing petak percobaan. Isi usus halus dan sekum diambil sebanyak \pm 3 gram kemudian dimasukkan pada wadah plastik selanjutnya dianalisis total bakteri asam laktat dan Coliform dengan menggunakan metode Total Plate Count (TPC). Penelitian menggunakan rancangan acak lengkap (RAL) dengan 4 perlakuan seperti yang tertera diatas. Tiap perlakuan terdiri dari 5 unit percobaan yang masingmasing terisi 12 ekor ayam broiler.

\section{T0 = Pakan Basal + 0,04\% Zinc Bacitracin selama 35 hari pemberian \\ $\mathrm{T} 1$ = Pakan Basal $+1 \%$ S. platensis selama 7 hari pemberian \\ $\mathrm{T} 2=$ Pakan Basal $+1 \%$ S. platensis selama 21 hari pemberian \\ T3 = Pakan Basal + 1\% S. platensis selama 35 hari pemberian}

Data diolah secara statistik menggunakan ANOVA dengan taraf kepercayaan 5\%. Apabila hasil F hitung menunjukkan pengaruh nyata maka dilanjutkan dengan uji wilayah ganda Duncan pada taraf 5\% (Steel and Torrie, 1995).
Hipotesis statistik :

$\mathrm{H}_{0}: \tau_{0}=\tau_{1}=\tau_{2}=0$ (lama waktu pemberian Spirulina platensis dalam ransum tidak berpengaruh terhadap total bakteri asam laktat dan Coliform pada ileum dan sekum ayam broiler).

$\mathrm{H}_{1}$ : minimal ada satu $\tau_{\mathrm{i}} \neq 0$ untuk $\mathrm{i}=0,1,2,3$ (lama waktu pemberian Spirulina platensis dalam ransum berpengaruh terhadap bakteri asam laktat dan Coliform pada ileum dan sekum ayam broiler).

Pengambilan hasil dari hipotesis adalah :

Apabila $\mathrm{F}$ hitung $<\mathrm{F}$ tabel dengan $\alpha=0,05$ maka $\mathrm{H}_{0}$ diterima dan $\mathrm{H}_{1}$ ditolak.

Apabila $\mathrm{F}$ hitung $\geq \mathrm{F}$ tabel dengan $\alpha=0,05$

maka $\mathrm{H}_{0}$ ditolak dan $\mathrm{H}_{1}$ diterima.

\section{HASIL DAN PEMBAHASAAN}

Hasil analisis statistik menunjukan bahwa adanya pengaruh $(\mathrm{P}<0,05)$ pemberian Spirulina platensis dalam ransum terhadap total Coliform pada Ileum ayam broiler akan tetapi tidak berpengaruh $(\mathrm{P}>0,05)$ pada total Coliform pada sekum. Perlakuan ini juga tidak menunjukan adanya berpengaruh $(\mathrm{P}>0,05)$ pada setiap perlakuan yang diberikan terhadap total bakteri asam laktat pada digesta ileum maupun sekum ayam broiler. Jumlah rataan total bakteri asam laktat dan Coliform dalam ileum dan sekum ayam broiler akibat penambahan Spirulina platensis dalam ransum disajikan pada Tabel 3. 
Tabel 3. Rataan Total Bakteri asam laktat dan Coliform dalam Ileum dan Sekum Ayam Broiler

\begin{tabular}{|c|c|c|c|c|}
\hline \multirow{2}{*}{ Variabel } & \multicolumn{4}{|c|}{ Perlakuan } \\
\hline & T0 & T1 & $\mathbf{T 2}$ & T3 \\
\hline Bakteri Asam laktat & \multicolumn{4}{|c|}{---------------------------------log(cfu/g)--------------------------- } \\
\hline Ileum & $8,67 \pm 0,42$ & $8,79 \pm 0,54$ & $8,69 \pm 0,52$ & $8,80 \pm 0,43$ \\
\hline Sekum & $8,71 \pm 0,44$ & $8,83 \pm 0,28$ & $8,72 \pm 0,26$ & $8,75 \pm 0,26$ \\
\hline \multicolumn{5}{|l|}{ Coliform } \\
\hline Ileum & $6,80 \pm 0,31^{\mathrm{a}}$ & $6,83 \pm 0,40^{\mathrm{a}}$ & $6,09 \pm 0,36^{\mathrm{b}}$ & $6,44 \pm 0,57^{\mathrm{ab}}$ \\
\hline Sekum & $6,45 \pm 0,19$ & $6,31 \pm 0,37$ & $5,83 \pm 0,77$ & $6,43 \pm 0,37$ \\
\hline
\end{tabular}

Superskrip yang berbeda pada baris yang sama menunjukkan adanya perbedaan nyata $(\mathrm{P}<0,05)$. T0 (Pakan Basal + 0,04\% Zinc Bacitracin), T1 (Pakan Basal + 1\% S. platensis selama 7 hari pemberian), T2 (Pakan Basal $+1 \%$ S. platensis selama 21 hari pemberian) dan T3 (Pakan Basal + $1 \%$ S. platensis selama 35 hari pemberian).

Total bakteri Coliform pada perlakuan T2 (pemberian Spirulina platensis selama 21 hari) memiliki rataan yang lebih rendah dibandingkan dengan perlakuan T0, T1, dan T3 pada ileum, akan tetapi total bakteri Coliform pada sekum memiliki rataan yang tidak jauh berbeda. Hal tersebut menunjukkan bahwa pemberian Spirulina platensis selama 21 hari efektif menurunkan bakteri Coliform. Sejatinya pemberian Spirulina platensis yang merupakan prebiotik diharapkan dapat meningkatkan total bakteri asam laktat dalam ileum maupun sekum sehingga dapat menurunkan total bakteri Coliform melalui mekanisme competitive exclusion (CE). Namun hal tersebut tidak terjadi pada penelitian ini, karena jumlah bakteri asam laktat yang hampir sama disetiap kelompok perlakuannya. Penurunan total bakteri Coliform pada perlakuan T2 pada penelitian ini menunjukan adanya senyawa lain dalam Spirulina platensis yang dapat menekan pertumbuhan bakteri Coliform. Senyawa antimikroba yang ditemukan pada cyanobacteria meliputi polifenol, asam lemak, glikolipid, terpenoid, alkaloid, dan berbagai bakteriosin yang belum dijelaskan (Sudha et al., 2011). Zat antimikroba dalam spirulina berperan dalam menghambat pertumbuhan bakteri patogen khususnya Coliform. Menurut Jamil et al. (2015) penambahan Spirulina kurang dari 1\% pada ayam broiler membuat sistem pertahanan tubuh menjadi meningkat dengan cara mengurangi atau membunuh mikroba patogen, dan meningkatkan aktivitas T-cell. Mekanisme kerja senyawa antimikroba yaitu dengan cara merusak dinding sel yang mengakibatkan pertumbuhan dinding sel terhambat, menghambat kerja enzim intraseluler sehingga metabolisme dalam sel terganggu serta mendenatursi protein sel.

Hasil analisis statistik menunjukkan bahwa tidak adanya berpengaruh $(\mathrm{P}>0,05)$ pada setiap perlakuan yang diberikan terhadap total bakteri asam laktat pada digesta ileum maupun sekum ayam broiler. Total bakteri asam laktat yang dihasilkan pada penelitian ini masih tergolong dalam kisaran normal. Menurut Raheem et al., (2012) yang menyatakan bahwa total bakteri asam laktat dalam usus halus ayam broiler secara umum yaitu 8,19 log cfu/g, sedangkan total bakteri asam laktat dalam sekum ayam broiler secara umum yaitu mencapai 8,81 log cfu/g. Hasil penelitian ini tidak berbeda 


\section{J. Ilmu-Ilmu Peternakan 28 (1):65 - 72}

dengan penelitian yang telah dilakukan oleh Shanmugapriya et al., (2015) yang menyatakan bahwa penambahan Spirulina platensis sebanyak 1\% menghasilkan total bakteri asam laktat pada ileum sebesar 8,283 $\pm 2,85 \log \mathrm{cfu} / \mathrm{g}$ sedangkan pada sekum 8,050 $\pm 2,85 \log c f u / g$.

Spirulina platensis mengandung protein yang tinggi dengan asam amino yang cukup lengkap dan kaya akan polisakarida yang berfungsi sebagai sumber nutrien bagi bakteri asam laktat (Hadebe and Odhav, 2016). Polisakarida yang tersusun atas galaktosa, glukosa, ramnosa, xylose, fruktosa, manosa dan asam uronat merupakan golongan gum yang merupakan bentuk serat pangan yang larut dalam air. Serat ini merupakan bahan tumbuhan yang tidak dapat diuraikan oleh sistem pencernaan akan tetapi dapat difermentasi oleh bakteri dalam saluran pencernaan (Senditya dkk., 2014). Namun, pada penelitian ini polisakarida dan protein yang terdapat dalam Spirulina platensis kurang mampu menstimulasi pertumbuhan bakteri asam laktat. Tidak berpengaruhnya perlakuan terhadap jumlah bakteri asam laktat dikarenakan perlakuan yang diberikan meningkatkan nilai $\mathrm{pH}$ pada saluran pencernaan menjadi netral. Nilai $\mathrm{pH}$ pada ileum perlakuan T1, T2, dan T3 sebesar 5,76; 6; 6,06. Nilai $\mathrm{pH}$ pada sekum perlakuan $\mathrm{T} 1$, T2, dan T3 sebesar 6,06; 6,23; dan 6,44. Menurut Widodo (2010) yang menyatakan bahwa kondisi $\mathrm{pH}$ pada setiap bagian dalam saluran pencernaan dapat berpengaruh terhadap perkembangan berbagai mikroba dalam saluran pencernaan dan efektivitas proses pencernaan karena enzim dan produk yang disekresikan mikroba mempunyai karakteristik spesifik serta mempunyai sensitivitas terhadap kondisi pH. Bakteri asam laktat memiliki kecenderungan untuk dapat berkembang dengan optimal pada $\mathrm{pH}$ rendah, sehingga pada $\mathrm{pH}$ yang relatif tinggi (akibat lama pemberian Spirulina platensis) bakteri asam laktat tidak dapat berkembang dengan baik.

\section{KESIMPULAN}

Berdasarkan hasil penelitian dapat disimpulkan bahwa Spirulina platensis berpotensi menjadi pengganti antibiotik yang lebih efektif menurunkan total Bakteri Coliform dalam ileum dan sekum ayam broiler. Pemberian Spirulina platensis selama 21 hari mampu menurunkan total bakteri Coliform dalam ileum ayam broiler.

\section{DAFTAR PUSTAKA}

de Caire, G.Z., de Cano, M.S., de Mule, M.C.Z., de Halperin, D.R., Galvagno, M.A. 1987. Action of cellfree extracts and extracellular products of Nostac muscorum on growth of Sclerotinia sclerotiorum. Phyton 47. 43-46

Hadebe, N., and B. Odhav. 2016. Isolation and characterization of prebiotik oligosaccharides from algal extracts and their effect on gut microflora. Journal of Functional Foods.

Haryati, T. 2011. Probiotik dan prebiotik sebagai pakan imbuhan nonruminansia. WARTAZOA. 21 (3) : 125-132

Jamil, A. B. M. R., Md. R. Akanda., Md. M. Rahman, Md. A. Hossain dan Md. Siddiqul. 2015. Prebiotik competence of spirulina on the production performance of broiler 


\section{J. Ilmu-Ilmu Peternakan 28 (1):65 - 72}

chickens. J. Adv. Vet. Anim. Res. 2 (3) : 304-309

Krismiyanto, L., N. Suthama, dan H.I. Wahyuni. 2015. Keberadaan bakteri dan perkembangan caecum akibat penambahan inulin dari umbi dahlia (Dahla variabilis) pada ayam kampong persilangan periode starter. J. Ilmu-Ilmu Peternakan. 24 (3) : 5460

Mariey, Y.A., H. R. Samak, H.a. Aboukhasbhba, M.A.M. Sayed and A. E. Abou-Zeid. 2014. Effect of using Spirulina platensis algae as a feed additive for poulty diets : 2productive performance of broiler. Egyptian Poulty Journal. 34 (1) : 245-258

Murdiati, T. B. 1997. Pemakaian antibiotika dalam usaha peternakan. WARTAZOA. 6 (1) : 18-22

Raheem, S. M. A., S. M. S. A. Allah and K. M. A. Hassanein. 2012. The effects of prebiotic, probiotic and symbiotic supplementation on intestinal microbial ecology and histomorphology of Broiler Chickens. J. IJAVMS. 6 (4): 277 289.

Senditya, M., M. S. Hadi., T. Estiasih dan E. Saparianti. 2014. Efek prebiotik dan sinbiotik simplisia daun cincau hitam (Mesona palustris BL) secara in vivo. Jurnal Pangan dan Argoindustri. 2 (3) : 141-151

Shanmugapriya, B., S. S. Babu, T. Hariharan, S. Sivaneswaran, M. B. Anusha, and
0.P. U. Raja. 2015. Synergistic effect of Spirulina platensis on performance and gut microbial of broiler chicks. Indo-Asian Journal of Multidisciplinary Research (IAJMR). 1 (2) : 149-155

Sudha, S.S., R. Karthic, J. Rengaramanujam, and Athulya. 2011. Antimicobial activity of Spirulina platensis and Aphanothece sp. On selected clinical bacteria isolates and its Antioxidant activity. South As. J. Bio. Sci. 1 (2) : 87-98

Tangendjaja, B. 2014. Estimation Feed Grains Demand in Indonesia. Country Report. FAO Rome

Widodo, E. 2010. Nutrisi dan Teknik Pemeliharaan Ayam Organik. Universitas Brawijaya Press, Malang. 